\title{
Screening Antimicrobial Peptides In Vitro for Use in Developing Transgenic Citrus Resistant to Huanglongbing and Citrus Canker
}

\author{
Ed Stover ${ }^{1}$, Richard R. Stange, Jr., and T. Gregory McCollum \\ U.S. Department of Agriculture, Agricultural Research Service, U.S. Horticultural Research \\ Laboratory, 2001 S. Rock Road, Fort Pierce, FL 34945
}

Jesse Jaynes

College of Agriculture, Environment and Nutrition Sciences, and College of Veterinary Medicine, Nursing \& Allied Health, Tuskegee University, Tuskegee, AL 36088

Michael Irey

U.S. Sugar Corporation, 111 Ponce de Leon Avenue, Clewiston, FL 33440

Erik Mirkov

Texas A\&M University, 2415 E. Hwy 83, Weslaco, TX 78596

\begin{abstract}
Additional Index words. Agrobacterium tumefaciens, Candidatus Liberibacter asiaticus, hemolytic activity, minimal inhibitory concentration, Sinorhizobium meliloti, Xanthomonas citri ssp. citri.

Abstract. Huanglongbing \{HLB [associated with Candidatus Liberibacter sp. (CLas)]\} and asiatic citrus canker \{ACC [causal organism Xanthomonas citri ssp. citri (XCC)]\} are bacterial diseases that seriously threaten sustainability of the Florida citrus (Citrus sp.) industry. Sweet orange (Citrus sinensis) and grapefruit (Citrus paradisi) are highly susceptible to ACC and improvement through conventional breeding is a long-term process, making transgenic solutions attractive. No strong HLB resistance has been identified within cultivated citrus scion types: creation of transgenic citrus that would permit economic citrus production where HLB is endemic is a high priority. Little is known about the HLB pathosystem and thus broad-spectrum antimicrobial peptides (AMPs) have been the focus for current work, and identification of safe and effective transgenes is essential to our efforts. In vitro assessment of minimum inhibitory concentration (MIC) for 44 AMPs was conducted using Sinorhizobium meliloti and Agrobacterium tumefaciens as surrogates for the unculturable CLas because they are closely related alpha proteobacteria (class Alphaproteobacteria). XCC is also a gram-negative bacterium and was included in these analyses in anticipation that HLB and ACC resistance can be achieved with the same AMP transgene if expressed using non-tissuespecific promoters. Twenty AMPs from diverse sources were initially tested. AMPs with the lowest MICs included tachyplesin I from horseshoe crab (Tachypleus tridentatus), SMAP-29 from sheep (Ovis aries), D4E1 and D2A21 (which are synthetic AMPs derived through evaluation of critical amino acid residues in AMPs, overall peptide structure, and AMP effectiveness), the human (Homo sapiens) LL-37, and the honeybee (Apis mellifera) venom AMP melittin. These AMPs inhibited growth of all three test bacterial species at $1 \mu M$ or less. An additional 20 synthetic AMPs were designed based on structures of the most effective AMPs and seven of these showed effectiveness at $1 \mu M$ or less across all three test bacteria. Most AMPs were comparable in effectiveness across the three bacterial species, but some species $\times$ AMP interactions were observed. Hemolytic activity was assessed by exposure of porcine erythrocytes (from Sus scrofa) to the AMPs. Hemolysis from most AMPs was not significantly different from water, whereas melittin was highly hemolytic.
\end{abstract}

Considerable effort is being devoted to developing transgenic citrus with resistance to huanglongbing and asiatic citrus canker. These bacterial diseases seriously threaten the sustainability of the Florida citrus industry. No strong HLB resistance has been identified within cultivated citrus scion types, compelling significant effort to develop transgenic lines that permit economic citrus production where HLB is endemic. Kumquats (Fortunella sp.) are highly resistant to ACC and some mandarin (Citrus

\footnotetext{
Received for publication 26 Sept. 2012. Accepted for publication 7 Jan. 2013. Thanks to AgroMed and Southern Gardens Citrus of U.S. Sugar for granting permission to publish this article covering material owned and provided by them, to Dr. William Dawson of the University of Florida for providing several custom synthesized AMPs used in the initial screening and to Dr. Robert Shatters, Jr. of USDA/ARS for providing the Sinorhizobium meliloti isolate $\mathrm{Sm}$ 1021. Dr. Jaynes designed the peptides for this study while a consultant for AgroMed, LLC.

${ }^{1}$ Corresponding author. E-mail: ed.stover@ars.usda.gov.
}

reticulata) types are tolerant (Peng et al., 2010); however, incorporation of strong ACC resistance through conventional breeding into the sweet orange and grapefruit types, which dominate the Florida citrus industry, may be a decades-long process. Cultivar characteristics are largely unchanged in transgenic plants; therefore, transgenic solutions for ACC are also an attractive option.

The CLas genomic sequence has been published (Duan et al., 2009) and is providing some targets specific to this pathogen; however, understanding of the HLB pathosystem remains quite limited. For this reason, broad-spectrum antimicrobial peptides have been the focus for much of the initial work to create HLBresistant transgenic citrus. AMPs have considerable promise in developing transgenic plants with disease resistance and have been subjects of numerous studies (e.g., reviewed in Düring, 1996; Marcos et al., 2008; Rajasekaran et al., 2009). AMPs offer an additional advantage that many are effective against multiple microorganisms offering the possibility that a single 
transgene may confer some resistance to a group of gramnegative bacterial pathogens, including the causal agents for HLB and ACC as well as Xylella fastidiosa the causal agent for citrus variegated chlorosis, a disease that has not yet been reported in the United States. Some AMPs may also offer resistance to fungal pathogens [Alternaria sp., Aspergillus sp., Botrytis cinerea, Cercospora sp., Claviceps purpurea, Colletotrichum destructivum, Fusarium sp., Magnaporthe grisea, Mycosphaerella musicola, Phytophthora sp., Pythium sp., and Verticillium dahliae (Rajasekaran et al., 2009)].

Because development of transgenic citrus and screening for disease resistance is extremely laborious, a series of AMPs were screened in vitro to assess their potential for providing resistance to HLB and ACC. Some AMPs also disrupt mammalian cells; therefore, screening for hemolysis of porcine corpuscles was also conducted.

\section{Materials and Methods}

Antimicrobial Peptides. The AMPs listed in Table 1 include many reported in the literature as occurring naturally in diverse organisms and were custom-synthesized based on reported amino acid sequences: apidaecin, drosocin, histatin-5, indolicidin, LL-37, pyrrhocoricin, and SMAP-29 were synthesized by AnaSpec (Fremont, CA); spinach defensin 2 (SoD2 from Spinacia oleracea), Cn-AMP-1, Ib-AMP-4, and P4c were synthesized by GenScript USA (Piscataway, NJ); and tachyplesin I was synthesized by Bachem Americas (Torrance, CA). The well-studied standard AMPs cecropin A, cecropin $\mathrm{B}$, magainin 1, magainin 2, and melittin were purchased from Sigma Chemical Co. (St. Louis, MO). The synthetic AMPs D4E1 and D2A21 were provided by AgroMed (Annapolis, MD).

DESIGNING AND PRODUCING ADDITIONAL SYNTHETIC Antimicrobial PePtides. Additional synthetic AMPs were designed by one of the authors (J. Jaynes) based on characteristics of the most promising animal AMPs. A series of 24 additional AMPs were synthesized (PolyPeptide Laboratories, San Diego, CA) through agreement with AgroMed and Southern Gardens Citrus (Clewiston, FL). The identities of these AMPs are indicated in Table 2 and are covered by either issued or pending patents.

DETERMINATION OF MINIMUM INHIBITORY CONCENTRATIONS. Test organisms were XCC (isolate Xsc 67D), A. tumefaciens [AT (isolate EHA 105)], and S. meliloti [SM (isolate Sm 1021)]. SM and AT were used as surrogates for the unculturable CLas because they are closely related alpha proteobacteria (Bastianel et al., 2005). Xsc 67D is a field isolate from symptomatic grapefruit leaves made on 28 Apr. 2006 from the U.S. Department of Agriculture, Ft. Pierce, FL, farm, with its identity confirmed by sequencing the product of the VM3/VM4 primer pair (Mavrodieva et al., 2004) and the pathogenicity of the isolate confirmed by presence of hyperplastic lesions on inoculated

Table 1. Activity of antimicrobial peptides (AMP) used in the first phase of this study: minimum inhibitory concentration against three bacterial species [Agrobacterium tumefaciens (AT), Sinorhizobium meliloti (SM), and Xanthomonas citri ssp. citri (XCC)] and percent hemolysis of porcine erythrocytes.

\begin{tabular}{|c|c|c|c|c|c|c|}
\hline \multirow[b]{2}{*}{ AMP } & \multirow[b]{2}{*}{ Source } & \multicolumn{4}{|c|}{ Minimum inhibitory concn against designated species $(\mu \mathrm{M})^{\mathrm{z}}$} & \multirow[b]{2}{*}{ AMP citation } \\
\hline & & AT & SM & $\mathrm{XCC}$ & Hemolysis $(\%)^{\mathrm{y}}$ & \\
\hline Tachyplesin I & Crustacean & 0.3 & 0.3 & 0.3 & 3.0 & Kawano et al., 1990 \\
\hline SMAP-29 & Sheep & 1 & 0.3 & 1 & 3.2 & Skerlavaj et al., 1999 \\
\hline $\mathrm{D} 4 \mathrm{E} 1^{\mathrm{x}}$ & Synthetic & 1 & 0.3 & 1 & 3.6 & Ballweber et al., 2002 \\
\hline $\mathrm{D} 2 \mathrm{~A} 21^{\mathrm{x}}$ & Synthetic & 1 & 0.3 & 1 & 8.4 & Ballweber et al., 2002 \\
\hline LL-37 & Human & 1 & 1 & 1 & 5.1 & Dürr et al., 2006 \\
\hline Melittin & Insect & 1 & 1 & 1 & 100.8 & Blondelle and Houghten, 1991 \\
\hline Cecropin A & Insect & 3 & 3 & 10 & 1.1 & Gudmundsson et al., 1991 \\
\hline Cecropin B & Insect & 10 & 3 & 10 & 1.2 & Gudmundsson et al., 1991 \\
\hline Indolicidin & Cow & 10 & 3 & 3 & 2.0 & Selsted et al., 1992 \\
\hline Apidaecin IA & Insect & $>30$ & 1 & $>30$ & 1.6 & Casteels et al., 1989 \\
\hline Drosocin & Insect & $>30$ & 3 & $>30$ & 1.6 & Gobbo et al., 2002 \\
\hline$\alpha$-Purothionin & Plant & 30 & 10 & 1 & 22.5 & Ohtani et al., 1977 \\
\hline Pyrrhocoricin & Insect & $>30$ & 10 & $>30$ & 1.9 & Cociancich et al., 1994 \\
\hline Magainin 1 & Frog & $>30$ & $>30$ & $>30$ & 1.3 & Zasloff, 1987 \\
\hline Magainin 2 & Frog & $>30$ & $>30$ & $>30$ & 1.5 & Zasloff, 1987 \\
\hline Histatin-5 & Human & $>30$ & $>30$ & $>30$ & 1.8 & Oppenheim et al., 1986 \\
\hline $\mathrm{Ib}-4$ & Plant & $>30$ & $>30$ & $>30$ & $\mathrm{ND}^{\mathrm{w}}$ & Taylor et al., 1997 \\
\hline Cn-1 & Plant & $>30$ & $>30$ & $>30$ & ND & Mandal et al., 2009 \\
\hline $\mathrm{P} 4 \mathrm{c}$ & Plant & $>30$ & $>30$ & $>30$ & ND & Suarez et al., 2005 \\
\hline SoD2 & Plant & $>30$ & $>30$ & $>30$ & ND & Segura et al., 1998 \\
\hline
\end{tabular}

${ }^{\mathrm{z}} \mathrm{AMPs}$ tested at $0,0.03,0.1,0.3,1,3,10$, and $30 \mu \mathrm{M}$ with three replicates of each. Initiated with $10^{7}$ colony-forming units/mL in each well in plate, incubated at $20^{\circ} \mathrm{C}$, and absorbance was read at $\mathrm{A}_{630}$. Minimum inhibitory concentration values indicate the lowest concentration in which no growth was detected after $48 \mathrm{~h}$ incubation.

${ }^{\mathrm{y}} \mathrm{Hemolytic}$ activities of AMPs were assessed at $10 \mu \mathrm{M}$. The positive control was $0.1 \%$ Triton X-100 (Dow Chemical Co., Midland, MI) and the negative control was phosphate-buffered saline (PBS) at $\mathrm{pH}$ 7.4. Test solutions of AMPs were mixed with porcine erythrocytes and were incubated at $38.5^{\circ} \mathrm{C}$ for $30 \mathrm{~min}$, centrifuged, diluted $10 \times$ in PBS, and absorbance was read at $\mathrm{A}_{580}$. Percent hemolysis was calculated relative to $100 \%$ hemolysis with Triton X-100.

${ }^{\mathrm{x}}$ AMPs tested through agreement with AgroMed (Annapolis, MD) and covered by either issued or pending patents.

"Not determined. 
Table 2. Minimum inhibitory concentration (MIC) against three bacterial species [Agrobacterium tumefaciens (AT), Sinorhizobium meliloti (SM), and Xanthomonas citri ssp. citri (XCC)], percent hemolysis of porcine erythrocytes, and physical characteristics of synthetic antimicrobial peptides (AMPs) studied in second phase of this work. ${ }^{\mathrm{z}}$

\begin{tabular}{|c|c|c|c|c|c|c|c|}
\hline Name & Sequence $^{\mathrm{y}}$ & $\begin{array}{l}\text { AA } \\
\text { (no.) }\end{array}$ & $\begin{array}{l}\text { Molecular } \\
\text { wt }\end{array}$ & AT & SM & $\mathrm{XCC}$ & $\begin{array}{l}\text { Hemolysis } \\
(\%)^{\mathrm{x}}\end{array}$ \\
\hline AGM151 & FAKRFVKKFRRIKKFLRFAFVF & 23 & 3641 & 3 & 0.3 & 3 & 21.4 \\
\hline AGM152 & FALALKALKKALKKLKKALKKAL & 23 & 3150 & 1 & 0.3 & 1 & 9.3 \\
\hline AGM153 & FAKKFAKKFKKFAKKFAKFAFAF & 23 & 3388 & 1 & 0.3 & 1 & 10.5 \\
\hline AGM154 & QHWSWGLRPGFAKKFAKKFKKFAKKFAKFAFAF & 33 & 4712 & 1 & 0.3 & 1 & 18.2 \\
\hline AGM155 & FKLRAKVKIRLRAKIKL & 17 & 2636 & 1 & 0.1 & 1 & 1.6 \\
\hline AGM156 & FAFAFKAFKKAFKKFKKAFKKAF & 23 & 3388 & 1 & 0.3 & 1 & 5.7 \\
\hline AGM157 & QHWSWGLRPGFAFAFKAFKKAFKKFKKAFKKAF & 33 & 4712 & 10 & 1 & 3 & 19.4 \\
\hline AGM158 & $\begin{array}{l}\text { FAFAFKAFKKAFKKFKKAFKKAFGPGRFAKKFAKKFKKFAKK } \\
\text { FAKFAFA }\end{array}$ & 50 & 7103 & 10 & 0.3 & 10 & 29 \\
\hline AGM159 & $\begin{array}{l}\text { FAFAFKAFKKAFKKFKKAFKKAFGPGRFAKKFAKKFKKFAKK } \\
\text { FAKFAFAC }\end{array}$ & 51 & 7207 & 10 & 0.3 & 10 & 32.3 \\
\hline AGM170 & $\begin{array}{l}\text { FARKFAKRFKKFARRFAKFAFAFGPGRFAFAKAFRRAFKKFRK } \\
\text { AFKRAF }\end{array}$ & 50 & 7327 & $>10$ & 1 & 10 & 39.4 \\
\hline AGM171 & $\begin{array}{l}\text { FARKFAKRFKKFARRFAKFAFAFGPGRFAFAKAFRRAFKKFRK } \\
\text { AFKRAFC }\end{array}$ & 51 & 7431 & $>30$ & $>30$ & $>30$ & 36.8 \\
\hline AGM172 & $\begin{array}{l}\text { FAFAFKAFRRAFKKFRKAFKRAFGPGRFARKFAKRFKKFARRF } \\
\text { AKFAFAF }\end{array}$ & 50 & 7327 & $>10$ & $>10$ & $>10$ & 43.1 \\
\hline AGM173 & $\begin{array}{l}\text { FAFAFKAFRRAFKKFRKAFKRAFGPGRFARKFAKRFKKFARRF } \\
\text { AKFAFAFC }\end{array}$ & 51 & 7431 & $>10$ & $>10$ & $>10$ & 50.9 \\
\hline AGM174 & FARKFAKRFKKFARRFAKFAFAF & 23 & 3501 & 1 & 3 & 1 & 17.6 \\
\hline AGM175 & FAFAFKAFRRAFKKFRKAFKRAF & 23 & 3501 & 1 & 1 & 1 & 16.3 \\
\hline AGM176 & FKIKARLRVKIKARLKL & 17 & 2636 & 1 & 1 & 1 & 1.3 \\
\hline AGM177 & CLRVKIRGPGRFRLKC & 16 & 2338 & $>30$ & $>30$ & 30 & 0.4 \\
\hline AGM178 & FRIRAKVKLRIRAKVRL & 17 & 2678 & 1 & 1 & 1 & 1.2 \\
\hline AGM179 & FRVKARIRLKVKARIRL & 17 & 2678 & 3 & 3 & 3 & 2.1 \\
\hline AGM180 & CKLRFRGPFRIKVRLC & 16 & 2338 & 30 & 30 & 30 & 0.6 \\
\hline AGM181 & KARLKFCFKGLCIKIKVR & 18 & 2647 & 3 & 0.3 & 1 & 23.9 \\
\hline AGM182 & KIKARLCLGKFCIKARLK & 18 & 2585 & 1 & 0.3 & 1 & 4.4 \\
\hline AGM183 & KAFKKAFKKFKKACFKGLCAKKFKKFAKKFAK & 32 & 4741 & 1 & 0.3 & 1 & 3.8 \\
\hline AGM184 & KFAKKFKKFAKKFCFKGLCAFKKAFKKFKKAF & 32 & 4777 & 1 & 0.3 & 1 & 4.1 \\
\hline D2A21 & FAKKFAKKFKKFAKKFAKFAFAF & 23 & 3388 & 1 & 0.3 & 1 & 8.4 \\
\hline D4E1 & FKLRAKIKVRLRAKIKL & 17 & 2636 & 1 & 0.3 & 1 & 3.6 \\
\hline
\end{tabular}

${ }^{\mathrm{z}}$ All AMPs in this table were tested through agreement with AgroMed (Annapolis, MD) and/or Southern Gardens Citrus (Clewiston, FL) and are covered by either issued or pending patents.

${ }^{y}$ AMPs tested at $0,0.03,0.1,0.3,1,3,10$, and $30 \mu \mathrm{M}$ with three replicates of each. Initiated with $10^{7}$ colony-forming units $/ \mathrm{mL}$ in each well in plate, incubated at $20^{\circ} \mathrm{C}$, and absorbance was read at $\mathrm{A}_{630}$. Minimum inhibitory concentration values indicate the lowest concentration in which no growth was detected after $48 \mathrm{~h}$ incubation. Values indicate the lowest concentration where no growth was detected after $48 \mathrm{~h}$ incubation.

${ }^{x}$ Hemolytic activities of AMPs were assessed at $10 \mu \mathrm{M}$. The positive control was $0.1 \%$ Triton X-100 (Dow Chemical Co., Midland, MI) and the negative control was phosphate-buffered saline (PBS) at $\mathrm{pH}$ 7.4. Test solutions of AMPs were mixed with porcine erythrocytes and were incubated at $38.5^{\circ} \mathrm{C}$ for $30 \mathrm{~min}$, centrifuged, diluted $10 \times$ in PBS, and absorbance was read at $\mathrm{A}_{580}$. Percent hemolysis was calculated relative to $100 \%$ hemolysis with Triton X-100.

grapefruit leaves. All studies used bacteria no more than two transfers from the stock culture.

AMPs were tested at concentrations of $0,0.03,0.1,0.3,1,3$, 10 , and $30 \mu \mathrm{M}$. Assays were performed in 96-well plates with lids (Nunc Nunclon D; Thermo Scientific, Rochester, NY). Each well contained $160 \mu \mathrm{L}$ of Luria Broth (Becton, Dickinson and Co., Franklin Lakes, NJ), $20 \mu \mathrm{L}$ bacterial suspension (targeting initial $10^{7}$ colony-forming units $/ \mathrm{mL}$ in each well), and $20 \mu \mathrm{L}$ AMP solution.

Plates were incubated at $20{ }^{\circ} \mathrm{C}$ and shaken for $20 \mathrm{~s}$ and absorbance was read at $\mathrm{A}_{630}$ at $0,16,20,24,40,44,48$, and $64 \mathrm{~h}$ of incubation using an Ultramark EX microplate imaging system (Bio-Rad Laboratories, Hercules, CA).

There were three replicates of each AMP concentration. Each plate contained three control wells with no bacteria. Assays of all three bacteria were made on a single 96-well plate. Each experiment was performed twice and results were identical or varied by a single dilution step in a few cases. MIC values were determined by examining plots of growth data and identifying the lowest concentration where there was no increase in $\mathrm{A}_{630}$ between 0 and $48 \mathrm{~h}$.

Determination of hemolytic aCtivity. Hemolytic activities of AMPs were measured using a slight modification of the method published by Park et al. (2007). Two milliliters of porcine blood (Lampire Biological Laboratories, Pipersville, PA) were washed three times by rinsing cells with $4 \mathrm{~mL}$ phosphatebuffered saline [PBS (pH 7.4)], mixing by gentle inversion, and centrifugation at $500 \mathrm{~g}_{\mathrm{n}}$ for $10 \mathrm{~min}$ at room temperature. Rinsed cells were mixed in $12 \mathrm{~mL}$ PBS and placed at $4{ }^{\circ} \mathrm{C}$ for $0.5 \mathrm{~h}$ to cool. Stocks of porcine blood were used within 1 week of receipt. 
It was determined (data not shown) that $10 \mu \mathrm{M}$ was the minimum concentration required to achieve $100 \%$ hemolysis with melittin, which has been extensively studied for its high hemolytic activity (Blondelle and Houghten, 1991), and so all AMPs were tested at this concentration. Stocks were made of each AMP at $100 \mu \mathrm{M}$ in PBS to produce test solutions. The positive control was $0.1 \%$ Triton X-100 (Dow Chemical Co., Midland, MI) and the negative control was PBS. Test solutions were $20 \mu \mathrm{L}$ of AMP solution added to $0.5-\mathrm{mL}$ microcentrifuge tubes and briefly cooled on ice before adding $180 \mu \mathrm{L}$ cooled suspended porcine cells to each tube. Solutions were mixed by drawing suspension gently back into the pipette and gently expelling one time. Tubes were incubated at $38.5^{\circ} \mathrm{C}$ for $30 \mathrm{~min}$, centrifuged $5 \mathrm{~min}$ at $4000 \mathrm{~g}_{\mathrm{n}}$, then $100 \mu \mathrm{L}$ of supernatant was added to $900 \mu \mathrm{L}$ PBS and absorbance was read at $\mathrm{A}_{\mathbf{5 8 0}}$. Percent hemolysis was calculated as: [(sample - blank $) /$ control $] \times 100$.

\section{Results and Discussion}

All experiments were highly reproducible for assessment of MIC and percent hemolysis. In all cases, data are presented from two identical experiments with three replicates of each treatment in each experiment.

INITIAL COMPARISON OF KNOWN ANTIMICROBIAL PEPTIDES. In comparison of widely diverse AMPs (Table 1), the lowest MICs (greatest ability to suppress microbial growth) were observed from tachyplesin I, SMAP-29 from sheep, D4E1 and D2A21 (which are synthetic AMPs derived through evaluation of critical amino acid residues in AMPs, overall peptide structure, and AMP effectiveness), the human LL-37, and the AMP melittin found in bee venom. All suppressed growth of the three bacterial species at $1 \mu \mathrm{M}$ or less and had hemolytic activity not significantly different from the buffer control, except melittin, which was as disruptive to porcine erythrocytes at $10 \mu \mathrm{M}$ as was $0.1 \%$ Triton X-100. The MICs observed in our study were comparable to those reported in earlier reports on in vitro activity of AMPs against plant pathogens (Badosa et al., 2007; Hammerschlag, 2004; Kuzina et al., 2006). The AMPs in this most active group displayed bacterial suppression at concentrations 0.1 to 0.33 times the MIC observed for cecropins A and $\mathrm{B}$, which are among the most highly studied AMPs for inducing transgenic plant resistance to bacterial diseases (Düring, 1996; Rajasekaran et al., 2009).

Because use of animal or human transgenes in food products might generate considerable consumer concern, we are committed to using transgenes of plant or synthetic origin. Unfortunately, none of the plant-derived AMPs selected for evaluation displayed strong activity in the in vitro assay. Therefore, efforts were made to identify synthetics AMPs with enhanced antimicrobial activity.

Additional synthetic antimicrobial peptide Variants. Twenty-four potentially enhanced synthetic AMPs were designed (Table 2), many as modifications of the D4E1 and D2A21 synthetic peptides, which looked promising in the initial comparison. Many of these variants resulted in negligible changes in MIC or hemolysis, and none resulted in significantly enhanced suppression of the test species. Influences of structural variants on MIC were interesting with some having no effect, some increasing MIC for some but not all test species, and some variants increasing MIC for all three test species (Table 3). Changes in hemolysis showed little relationship to effects on MIC.

SYNTHETIC ANTIMICROBIAL PEPTIDE VARIANTS BASED ON TACHYPLESIN I. By assessing the hydrophobicity/hydrophilicity, charge, and volume of each amino acid in tachyplesin I, new amino acid sequences with similar physiochemical traits were developed.

Table 3. Summary analysis of results from Table 2 describing effects from alteration of synthetic antimicrobial peptide (AMP) structure on minimum inhibitory concentration (MIC) against three bacterial species [Agrobacterium tumefaciens (AT), Sinorhizobium meliloti (SM), and Xanthomonas citri ssp. citri (XCC)], and percent hemolysis of porcine erythrocytes. ${ }^{z}$

\begin{tabular}{|c|c|c|c|}
\hline Test AMP & $\begin{array}{l}\text { Structural alterations } \\
\text { in amino acids (AA) }\end{array}$ & $\begin{array}{c}\text { Effect of change } \\
\text { on MIC }\end{array}$ & $\begin{array}{c}\text { Effect of change } \\
\text { on hemolysis }\end{array}$ \\
\hline AGM 155 & $\begin{array}{l}\text { D4E1 with three AAs in the middle changed from } \\
\mathrm{IKV}^{\mathrm{y}} \text { to VKI }\end{array}$ & None & None \\
\hline AGM173 & AGM 172 with terminal $\mathrm{C}$ on carboxy-terminus & None & None \\
\hline AGM175 & AGM174 reversed & None & None \\
\hline AGM176 & $\begin{array}{l}\text { Middle } 15 \text { AA of D4E1 reversed but with same amino } \\
\text { and carboxy termini }\end{array}$ & None & None \\
\hline AGM180 & AGM177 reversed & None & None \\
\hline AGM171 & AGM 170 with $\mathrm{C}$ on carboxy-terminus & $\begin{array}{l}\text { MIC increased } 3 \text { concentration increments } \\
\text { for SM but only } 1 \text { concentration increment } \\
\text { higher for AT and XCC }\end{array}$ & None \\
\hline AGM154 & $10 \mathrm{AA}$ added on amino-terminus of $\mathrm{D} 2 \mathrm{~A} 21$ & None & Increased \\
\hline AGM157 & $10 \mathrm{AA}$ added on amino-terminus of a reversed D2A21 & $\begin{array}{l}\text { MIC increased 1-2 concentration increments } \\
\text { for AT, SM and XCC }\end{array}$ & Increased \\
\hline
\end{tabular}

${ }^{\mathrm{z}}$ All AMPs in this table were tested through agreement with AgroMed (Annapolis, MD) and Southern Gardens Citrus (Clewiston, FL) and are covered by either issued or pending patents.

${ }^{\mathrm{y}}$ Amino acids indicated by single letter code convention. 
Figure 1 depicts a proprietary system developed by J. Jaynes of AgroMed to compare and substitute amino acids to create peptides with similar physiochemical characteristics (described in Rajasekaran et al., 2009). Figure 2 shows the structures of the AGM 181 through 184 modeled on tachyplesin I. The design

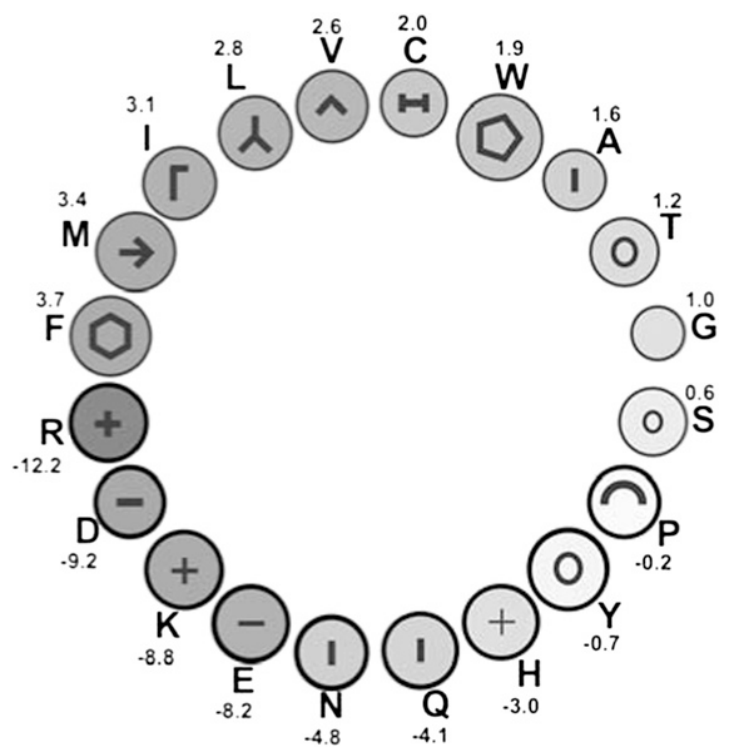

Fig. 1. A proprietary system developed by J. Jaynes of AgroMed (Annapolis, MD) to help visualize the role played by individual amino acids in an antimicrobial peptide. Degree of hydrophobicity is indicated by intensity of gray color with thin bordered rings and hydrophilicity by intensity of gray color with thick bordered rings and is also shown here by the associated number which is the hydrophobicity in kilocalories per mole and is the amount of energy necessary to move the amino acid from a membrane interior to the exterior when in an $\alpha$-helical protein. Charge of the amino acids is indicated and diameter is indicative of the van der Waal's radius of each amino acid when present in a peptide.
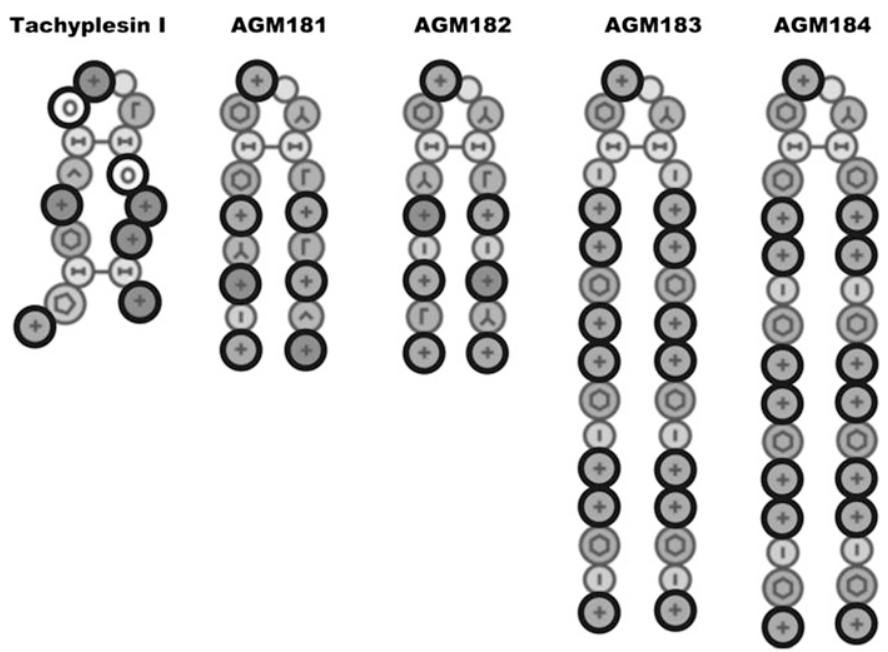

Fig. 2. Tachyplesin I and four synthetic peptides with similar physiochemical properties. Degree of hydrophobicity is indicated by intensity of gray color with thin-bordered rings and hydrophilicity by intensity of gray color with thick-bordered rings and is also shown here by the associated number, which is the hydrophobicity in kilocalories per mole and is the amount of energy necessary to move the amino acid from a membrane interior to the exterior when in an $\alpha$-helical protein. Charge of the amino acids is indicated and diameter is indicative of the van der Waal's radius of each amino acid when present in a peptide. goal was to maximize activity while at the same time achieving negligible toxicity. AMPs where both MICs and hemolysis in vitro are very low would then be those peptides selected for further testing.

All newly synthesized AMPs had very similar MICs to tachyplesin I, but AMG181 had markedly higher hemolysis than the others. Similarity of MIC values within this group validates the physiochemical substitution system used in creation of these synthetic AMPs.

Efforts to create improved synthetic AMPs resulted in no increase in activity against target bacteria, as indicated by MIC from the in vitro assays. This may indicate a ceiling for activity inherent in AMPs. However, it is possible that some of these synthetics will have other desirable properties regarding resistance to proteolysis or ability to accumulate in specific tissues in plants and, therefore, merit testing as transgenes. Certainly design and testing of AMPs offer substantial opportunity for better understanding interactions between AMPs and hosts or targets as affected by amino acid sequence.

ANTIMICROBIAL PEPTIDE $\times$ SPECIES INTERACTION. Most AMPs were very similar in effectiveness across the three species, showing growth suppression at either identical MICs or within one tested concentration increment (AMPs were tested at concentrations increasing $\approx 3$-fold in each adjoining category). However, some bacterial species $\times$ AMP interactions were observed. Most notably, apidaecin IA and drosocin were more effective against SM than AT or XCC, showing no suppression of AT or XCC at any concentration tested (the maximum tested was $30 \mu \mathrm{M}$ ) but suppressing SM at 1 to $3 \mu \mathrm{M}$. $\alpha$-purothionin demonstrated much greater effectiveness against XCC than AT or SM. Such species $\times$ AMP interactions likely relate to interactions between bacterial membrane structures and motifs in the AMPs displaying specificity (Huang, 2000), and further study may ultimately permit design of AMPs with considerable specificity against targeted organisms.

RELATIONSHIP BETWEEN IN VITRO ANTIMICROBIAL PEPTIDE ACTIVITY AND ACTIVITY IN PLANTA. Although in vitro assays of AMPs are much faster than tests of transgenic genes in planta for species where transgenesis is inefficient, there are also significant limitations. Activity of a gene in a transformed plant can be substantially different from performance in vitro; therefore, in vitro data can provide some guidance on AMP selection but must be considered with caution. Transgenically expressed spinach defensin (SoD2) has shown substantial activity against the diseases ACC and HLB in greenhouse and field trials of citrus (E. Mirkov, unpublished data). However, in our in vitro system, there was no suppression of growth on any of the three test organisms at the highest concentration tested. SoD2 has multiple cysteine disulfide bridges (Segura et al., 1998), which stabilize the secondary structure that is likely critical to antimicrobial activity (Broekaert et al., 1995), and the peptide may not have undergone proper folding and crosslinking when chemically synthesized. Caution should be used in testing synthesized peptides that may require post-translational processing to achieve functional conformations, although many of the AMPs that were quite effective in our assays also include cysteine disulfide bridges (e.g., Kawano et al., 1990). In vitro assessment may provide an initial screen to determine promising AMPs but it may also substantially underestimate activity of peptide sequences requiring post-translational modifications. In addition, very frequently amphipathic AMPs are more effective in planta than in vitro and there is evidence that AMPs 
in vitro form large aggregates that hinder function, whereas in planta, AMPs likely exist as discrete molecules or much smaller aggregates (J. Jaynes, unpublished data).

Progress in implementing antimicrobial PePtideEXPRESSING TRANSGENICS FOR HUANGLONGBING RESISTANCE IN CITRUS. D4E1, a 17 amino acid synthetic AMP, which forms a beta sheet (Lucca et al., 1998), was among the most active AMPs in our in vitro assays. D4E1 was active against AT expressed as a transgene in hybrid poplar [Populus tremula $\times$ $P$. alba (Mentag et al., 2003)] and has been used extensively in initial efforts to create HLB-resistant transgenic citrus in the citrus improvement program at the U.S. Horticultural Research Laboratory, Fort Pierce, FL. Despite significant AMP design modifications intended to enhance activity, the lack of increased AMP effectiveness in this report suggests that other approaches may be desirable for enhancing efficacy. There are reports of synergistic effects in combining diverse AMPs (e.g., Yan and Hancock, 2001) and transgenic tobacco (Nicotiana tabacum) simultaneously expressing two different spinach defensins appear to be more effective in suppressing Candidatus Liberibacter solanacearum than either defensin expressed alone (E. Mirkov, unpublished data). In our studies as part of the current report, combining diverse AMPs in in vitro tests was always strictly additive in their effect (data not shown). A combination of AMPs may provide the additional benefit of helping suppress development of pathogens resistant to a single AMP.

Improved transgene expression is sometimes realized by inclusion of a transit sequence to concentrate proteins in critical tissues for activity of the transgenic product and/or with greater protection from proteolysis (summary in Frank et al., 2011). However, for HLB, the causal pathogen is located exclusively in phloem sieve elements (Bové, 2006) and a suitable transit peptide to target these cells is not apparent.

Chimeral peptides that combine AMP motifs with other sequences having high affinity to bacterial membranes may permit markedly greater AMP effectiveness at similar expression levels. Effectiveness of such a chimeral peptide was recently demonstrated to enhance resistance to pierce's disease (caused by $X$. fastidiosa) in genetically engineered grapevine [Vitis vinifera (Dandekar et al., 2012)].

These approaches are being implemented in the next generation of citrus AMP transgenics.

\section{Literature Cited}

Badosa, E., R. Ferre, M. Planas, L. Feliu, E. Besalú, J. Cabrefiga, E. Bardají, and E. Montesinos. 2007. A library of linear undecapeptides with bactericidal activity against phytopathogenic bacteria. Peptides 28:2276-2285.

Ballweber, L.M., J.E. Jaynes, W.E. Stamm, and M.F. Lampe. 2002. In vitro microbicidal activities of cecropin peptides D2A21 and D4E1 and gel formulations containing 0.1 to $2 \%$ D2A21 against Chlamydia trachomatis. Antimicrob. Agents Chemother. 46:34-41.

Bastianel, C., M. Garnier-Semancik, J. Renaudin, J.M. Bové, and S. Eveillard. 2005. Diversity of 'Candidatus Liberibacter asiaticus', based on the omp gene sequence. Appl. Environ. Microbiol. 71:6473-6478.

Blondelle, S.E. and R.A. Houghten. 1991. Hemolytic and antimicrobial activities of the twenty-four individual omission analogs of melittin. Biochemistry 30:4671-4678.

Bové, J.M. 2006. Huanglongbing: A destructive, newly-emerging, century-old disease of citrus. J. Plant Pathol. 88:7-37.

Broekaert, W.F., F.R.G. Terras, B.P.A. Cammue, and R.W. Osborn. 1995. Plant defensins: Novel antimicrobial peptides as components of the host defense system. Plant Physiol. 108:1353-1358.
Casteels, P., C. Ampe, F. Jacobs, M. Vaeck, and P. Tempst. 1989. Apidaecins: Antibacterial peptides from honeybees. EMBO J. 8: 2387-2391.

Cociancich, S., A. Dupont, G. Hegy, R. Lanot, F. Holder, C. Hetru, J.A. Hoffmann, and P. Bulet. 1994. Novel inducible antibacterial peptides from a hemipteran insect, the sap-sucking bug Pyrrhocoris apterus. Biochem. J. 300:567-575.

Dandekar, A.M., H. Gouran, A.M. Ibáñez, S.L. Uratsu, C.B. Agüero, S. McFarland, Y. Borhani, P.A. Feldstein, G. Bruening, R. Nascimento, L.R. Goulart, P.E. Pardington, A. Chaudhary, M. Norvell, E. Civerolo, and G. Gupta. 2012. An engineered innate immune defense protects grapevines from pierce disease. Proc. Natl. Acad. Sci. USA 109: 3721-3725.

Duan, Y.P., L.J. Zhou, D.G. Hall, W.B. Li, H. Doddapaneni, H. Lin, L. Liu, C.M. Vahling, D.W. Gabriel, K.P. Williams, A. Dickerman, Y.J. Sun, and T. Gottwald. 2009. Complete genome sequence of citrus huanglongbing bacterium, 'Candidatus Liberibacter asiaticus' obtained through metagenomics. Mol. Plant Microbe Interact. 22:1011-1020.

Düring, K. 1996. Genetic engineering for resistance to bacteria in transgenic plants by introduction of foreign genes. Mol. Breed. 2: 297-305.

Dürr, U.H.N., U.S. Sudheendra, and A. Ramamoorthy. 2006. LL-37, the only human member of the cathelicidin family of antimicrobial peptides. Biochimica Biophysica Acta-Biomembranes 1758:14081425.

Frank, M., G. Plesch, and P. Puzio. 2011. Method for producing a transgenic plant cell, a plant or a part thereof with increased resistance biotic stress (sic). U.S. Patent Application US 2011/ 0179523-A1. U.S. Patent Trademark Office, Washington, DC.

Gobbo, M., L. Biondi, F. Filira, R. Gennaro, M. Benincasa, B. Scolaro, and R. Rocchi. 2002. Antimicrobial peptides: Synthesis and antibacterial activity of linear and cyclic drosocin and apidaecin $1 \mathrm{~b}$ analogues. J. Med. Chem. 45:4494-4504.

Gudmundsson, G.H., D. Lidholm, B. Asling, R. Gan, and H.G. Boman. 1991. The cecropin locus. Cloning and expression of a gene cluster encoding three antibacterial peptides in Hyalophora cecropia. J. Biol. Chem. 266:11510-11517.

Hammerschlag, F.A. 2004. In vitro inhibitory activity of antimicrobial peptides cecropin, alpha-thionin DB4, and gamma-thionin RsAFP1 against several pathogens of strawberry and highbush blueberry. HortScience 39:1053-1055.

Huang, H.W. 2000. Action of antimicrobial peptides: Two state model. Biochemistry 39:8347-8352.

Kawano, K., T. Yoneya, T. Miyata, K. Yoshikawa, F. Tokunaga, Y. Terada, and S. Iwanaga. 1990. Antimicrobial peptide Tachyplesin I, isolated from hemocytes of the horseshoe crab (Tachypleus tridentatus). J. Biol. Chem. 265:15365-15367.

Kuzina, L.V., T.A. Miller, and D.A. Cooksey. 2006. In vitro activities of antibiotics and antimicrobial peptides against the plant pathogenic bacterium Xylella fastidiosa. Lett. Appl. Microbiol. 42:514-520.

Lucca, A.J., J.M. de Bland, C. Grimm, T.J. Jacks, J.W. Cary, J.M. Jaynes, T.E. Cleveland, and T.J. Walsh. 1998. Fungicidal properties, sterol binding, and proteolytic resistance of the synthetic peptide D4E1. Can. J. Microbiol. 44:514-520.

Mandal, S.M., S. Dey, M. Mandal, S. Sarkar, S. Maria-Neto, and O.L. Franco. 2009. Identification and structural insights of three novel antimicrobial peptides isolated from green coconut water. Peptides 30:633-637.

Marcos, J.F., A. Muñoz, E. Pérez-Payá, S. Misra, and B. López-García. 2008. Identification and rational design of novel antimicrobial peptides for plant protection. Annu. Rev. Phytopathol. 46:273-301.

Mavrodieva, V., L. Levy, and D.W. Gabriel. 2004. Improving sampling methods for real-time polymerase chain reaction diagnosis of citrus canker from field samples. Phytopathology 94:61-68.

Mentag, R., M. Luckevich, M.J. Morency, and A. Seguin. 2003. Bacterial disease resistance of transgenic hybrid poplar expressing the synthetic antimicrobial peptide D4E1. Tree Physiol. 23:405-411. 
Ohtani, S., T. Okada, H. Yoshizumi, and H. Kagamiyama. 1977. Complete primary structures of two subunits of purothionin A, a lethal protein for brewer's yeast from wheat flour. J. Biochem. 82:753-767.

Oppenheim, F.G., Y.-C. Yang, R.D. Diamond, D. Hyslop, G.D. Offner, and R.F. Toxler. 1986. The primary structure and functional characterization of the neutral histidine-rich polypeptide form human parotid secretion. J. Biol. Chem. 261:1177-1182.

Park, D.S., J.Y. Leem, E.Y. Suh, J.H. Hur, H.W. Oh, and H.Y. Park. 2007. Isolation and functional analysis of a 24-residue linear $\alpha$-helical antimicrobial peptide from Korean blackish cicada, Cryptotympana dubia (Homoptera). Arch. Insect Biochem. Physiol. 66:204-213.

Peng, Z.C., G.Z. Gong, S.C. Chen, G.B. Zhang, and Q.B. Hong. 2010. Screening of molecular marker putatively related with citrus canker resistance. Acta Hort. Sinica 37:383-389.

Rajasekaran, K., J.M. Jaynes, and J.W. Cary. 2009. Transgenic expression of lytic peptides in food and feed crops to control phytopathogens and preharvest mycotoxin contamination, p. 119-142. In: Appell, M. D.F. Kendra, and M.W. Trucksess (eds.). Mycotoxin prevention and control in agriculture. Amer. Chem. Soc. Symp. Ser. 1031. Amer. Chem. Soc., Washington DC.

Segura, A., M. Moreno, A. Molina, and F. García-Olmedo. 1998. Novel defensin subfamily from spinach (Spinacia oleracea). FEBS Lett. 435:159-162.
Selsted, M.E., M.J. Novotny, W.L. Morris, Y.-Q. Tang, W. Smith, and J.S. Cullor. 1992. Indolicidin, a novel bactericidal tridecapeptide amide from neutrophils. J. Biol. Chem. 267:4292-4295.

Skerlavaj, B., M. Benincasa, A. Risso, M. Zantetti, and R. Gennaro. 1999. SMAP-29: A potent antibacterial and antifungal peptide from sheep leukocytes. FEBS Lett. 463:58-62.

Suarez, M., M. Haenni, S. Canarelli, F. Fisch, P. Chodanowski, C. Servis, O. Michielin, R. Freitag, P. Moreillon, and N. Mermod. 2005. Structure-function characterization and optimization of a plantderived antibacterial peptide. Antimicrob. Agents Chemother. 49: 3847-3857.

Taylor, R.H., D.P. Acland, S. Attenborough, B.P.A. Cammue, I.J. Evans, R.W. Osborn, J.A. Ray, S.B. Rees, and W.F. Broekaert. 1997. A novel family of small cysteine-rich antimicrobial peptides from seed of Impatiens balsamina is derived from a single precursor protein. J. Biol. Chem. 272:24480-24487.

Yan, H. and E.W. Hancock. 2001. Synergistic interactions between mammalian antimicrobial defense peptides. Antimicrob. Agents Chemother. 45:1558-1560.

Zasloff, M. 1987. Magainins, a class of antimicrobial peptides from Xenopus skin: Isolation, characterization of two active forms, and partial cDNA sequence of a precursor. Proc. Natl. Acad. Sci. USA 84:5449-5453. 